\title{
Rheumatoid arthritis: hand function, activities of daily living, grip strength and essential assistive devices.
}

\author{
I Shipham, M Occ Ther (Pret), Department Occupational Therapy, University of \\ Pretoria/Pretoria Academic Hospital \\ SJS Pitout, B Occ Ther (Pret), Occupational Therapy, Pretoria Academic Hospital
}

\section{Abstract}

Persons with rheumatoid arthritis use assistive devices to enable them, in spite of impaired hand dexterity and grip strength, to manage Activities of Daily Living (ADL). The aim of the research was to lay the foundation for a list of essential assistive devices through

- determining which assistive devices for ADL were most often used and requested,

- investigating whether there was a correlation between grip strength and the

o number of assistive devices,

o duration of disease,

o degree of difficulty in performing ADL and by

- $\quad$ investigating whether there was a correlation between difficulty in ADL and

o number of assistive devices,

o duration of the disease.

\section{Study sample}

Fifty five persons, 42 females and 13 males, seen at the Pretoria Academic Hospital's Arthritis Clinic were recruited.

\section{Materials and methods}

- A questionnaire was used to determine the level of difficulty with ADL.

- Details about assistive devices were recorded.

- $\quad$ The modified sphygmomanometer was used to measure grip strength.

\section{Results}

- $\quad$ Assistive devices most in use were the tap turner and the dagger knife with built up handle.

- $\quad$ The highest correlation was found between grip strength and difficulty in ADL and between difficulty in ADL and the number of assistive devices used.

It seems therefore that loss of grip strength is the main indicator for assistive devices.

\section{Abstrak}

Persone met rumatoïde artritis gebruik hulpmiddels om hulle in staat te stel, om ten spyte van beperkte handvaardigheid en greepsterkte, Aktiwiteite van die Daaglikse Lewe (ADL) uit te voer. Die doel van die navorsing was om ' $n$ basis te lê vir ' $n$ lys van noodsaaklike hulpmiddels deur

- $\quad$ vas te stel watter huplmiddels die meeste gebruik en aangevra word.

- $\quad$ ondersoek in te stel na die korrelasie tussen greepsterkte en

o aantal huplmiddels,

o duur van die siekte en

o en moeilikheidsgraad in ADL en deur

- $\quad$ ondersoek in te stel na die korrelasie tussen moeilikheidsgraad in ADL en die

o aantal hulpmiddels,

o duur van die siekte.

\section{Studiesteekproef}

'n Groep van 55 persone, 42 dames en 13 mans, het aan die studie deelgeneem by die Artritiskliniek van die Pretoriase Akademiese Hospitaal.

\section{Materiale en metode}

- $\quad n$ Vraelys is gebruik om die moeilikheidsgraad in ADL te bepaal.

- Besonderhede oor hulpmiddels is ingewin.

- $\quad$ 'n Aangepaste sfigmomanometer is gebruik om greepsterkte mee te meet.

\section{Resultate}

- Hulpmiddels meeste in gebruik was kraanoopmakers en die mes met opgeboude dolkhandvatsel.

- Die hoogste korrelasie is gevind tussen greepsterkte en moeilikheidgraad in ADL en tussen moeilikheidsgraad in ADL en aantal hulpmiddels in gebruik.

Dit blyk dus dat verminderde greepsterkte die belangrikste indikasie vir die gebruik van hulpmiddels is. 
Introduction

\section{Implications of rheumatoid arthritis for everyday living}

Rheumatoid arthritis (RA) is a chronic and progressive systemic disease that affects connective tissue. It involves many joints, especially those of the hands and feet, leading to deformities and disability. According to Harris, cited in Dellhag and Burckhardt (1995:16), over ninety percent of people with rheumatoid arthritis are believed to have some involvement of their hand joints. This involvement often leads to diminished grip strength and difficulty with performing everyday tasks.

\section{Changes in health care delivery in South Africa}

With the implementation of the Primary Health Care approach fewer patients attend clinics at tertiary institutions where specialist arthritis services, including those of an occupational therapist, are available.

At present only patients with uncontrolled symptoms are seen at specialist clinics. Patients now receive their routine care at primary health care clinics and district hospitals. Very few of the latter institutions have the services of an occupational therapist.

At the specialist clinic for patients with arthritis at Pretoria Academic Hospital one of the functions of the occupational therapist is to give attention to impaired hand function. This includes the evaluation for and provision of assistive devices, also called technical aids or assistive technology.

Apart from the fact that very few primary health care clinics and district hospitals have the services of an occupational therapist, no assistive devices are available at these facilities.

\section{Aim of the research}

This study was done to lay a basis for a list of the most useful assistive devices for people with rheumatoid arthritis. Similar to the essential drugs list, these assistive devices could be kept in stock at primary health care sites and hospitals other than tertiary institutions. This would support the National Rehabilitation Policy (2000:18) in establishing and updating a list of basic assistive devices, and in making devices available for all those who need them.

\section{Objectives of the study}

The objectives of the study were to

- determine which assistive devices for manual activities were most often issued, used and requested

- $\quad$ investigate whether there was a correlation between grip strength and the

o number of assistive devices used,

o duration of disease, o degree of difficulty in performing ADL and

- $\quad$ investigate whether there was a correlation between difficulty in ADL and

o the number of assistive devices

o disease duration

\section{Main areas of concern}

The main areas of concern in Occupational Therapy in the management of rheumatoid arthritis are grip strength, activities of daily living and assistive devices.

\section{Grip strength}

There are several reasons why strength of the handgrip in rheumatoid arthritis is impaired (Melvin 1989: 440):

- $\quad$ The ability to apply strength becomes diminished when there is pain, active inflammation and swelling.

- Wrist tenosinovitis may impair flexor tendon gliding and thereby reduce applied strength of the long flexor muscles of the fingers.

- Loss of finger flexion due to contractures makes it difficult to apply strength in grasping thin or narrow handles.

Grip strength correlates well with functional indices and other assessments of disease activity (Myers, Grennan \& Palmer 1980: 369; Felson, Anderson, Boers, Bombarde, Chernoff, Fried, Furst, Goldsmith, Kieszak, Lightfoot, Paulus, Tugwell, Weinblatt, Widmark, Williams, Wolfe 1993: 738 ). According to Dellhag \& Burckhardt (1995: 19), grip strength is one of the predictors for actual and self-estimated hand function.

It is one component of hand evaluation that can be measured objectively, quickly and frequently and should be monitored.

\section{Activities of Daily Living}

In occupational therapy the concept of Activities of Daily Living (ADL) describes those activities or tasks that a person does every day to maintain independence (Reed \& Sanderson 1980: 227).

It is not difficult to imagine that decrease in grip strength and hand dexterity will lead to greater difficulty and pain during ADL.

\section{Assistive Devices}

Assistive devices contribute to an increase in independence in tasks that could otherwise not be performed, or performed only with difficulty.

They comprise "any item, piece of equipment or product system, whether acquired commercially, modified or customized, that is used to increase, maintain or improve the functional capabilities of individuals with disabilities" (Hopkins and Smith 1993: 326).

For persons with rheumatoid arthritis, pain reduction and increase in comfort during activity performance can be 


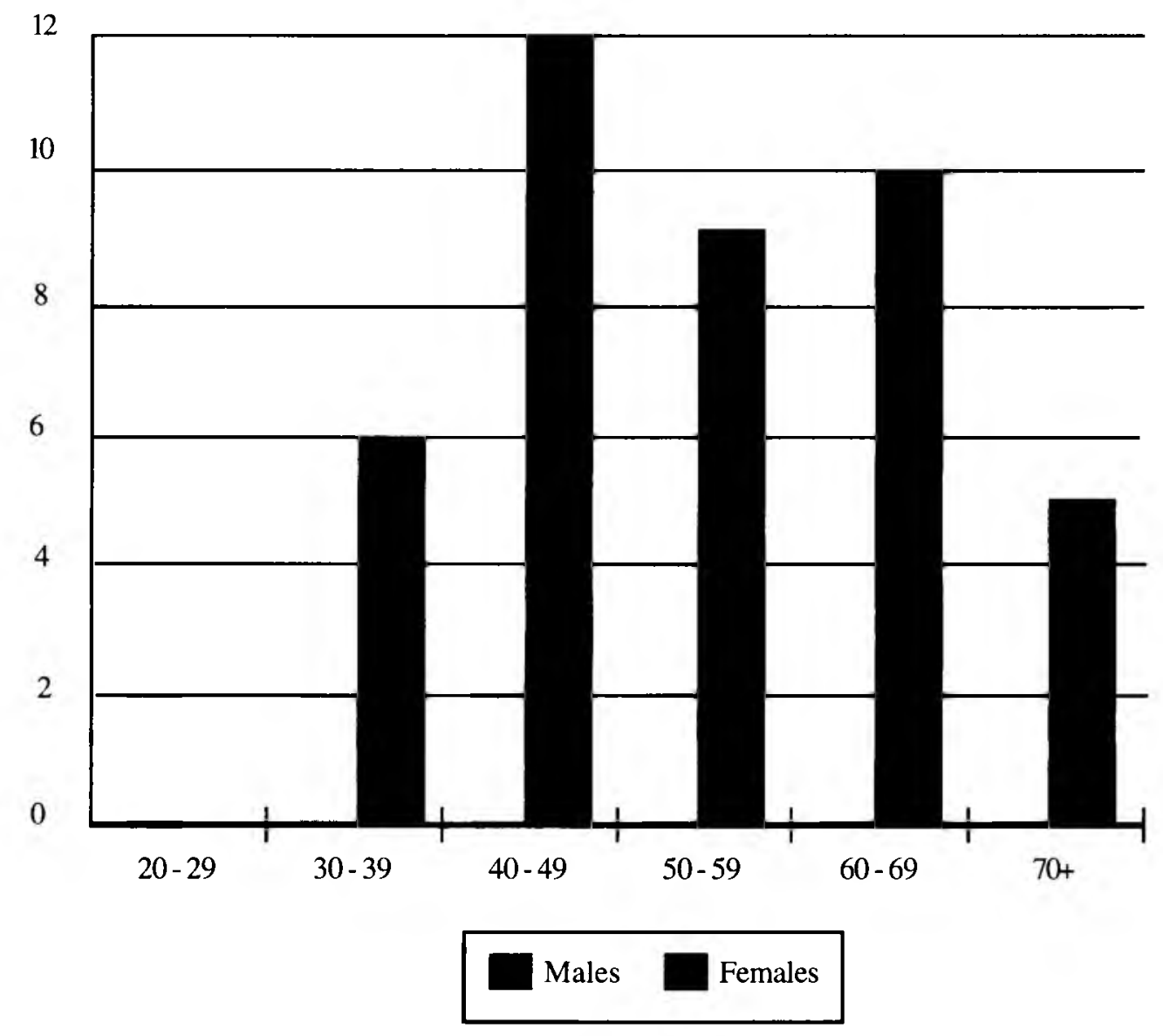

added to the above benefits. The use of assistive devices is reported to play a role in maintaining integrity of the joints. Avoiding tight grip was one of the joint protection principles for which Palmer \& Simons (1999:456) found evidence. This was supported by Shipham (1996: 35) who measured ulnar deviation of the metacarpal phalangeal joints during unresisted and resisted pinch. Results of the study showed that resistance significantly increases the extent of ulnar deviation, even in non-arthritic hands.

Evaluation for and education in the use of assistive devices form an integral part of arthritic patients' occupational therapy.

First world countries have developed and commercialised a large variety of assistive devices from which the occupational therapist can choose. Importation of these assistive devices is expensive, and this technology therefore remains relatively inaccessible to the South African population. In order to overcome this, a number of the commercially available devices have been modified, using appropriate design and locally available equipment, material and expertise.

Another approach to maximize arthritis sufferers' ability to perform daily activities would be to produce and market e.g. kitchen equipment, suitable for people with arthritis, to the general public. An additional advantage of this approach would be that people with arthritis would feel less "different".

Currently a variety of assistive devices at the Arthritis Clinic at Pretoria Academic Hospital are available, (see Table III). Although limited, this list of assistive devices is typical of assistive devices reported by Melvin (1989: 441) and Dellhag \& Bjelle (1999: 36) as being of value in the management of rheumatoid arthritis.

\section{The research design}

A cross sectional survey over a 4-month period at the Arthritis Clinic at Pretoria Academic Hospital was carried out.

\section{Population and sample}

The researchers recruited all the patients over the age of 18 diagnosed with rheumatoid arthritis that visited the clinic at Pretoria Academic Hospital between July and October 2000. This convenience sample was assumed to be reasonably representative of the patients with rheumatoid arthritis treated at the hospital.

A total of 55 patients ( 42 female and 13 male) were included in the study. The racial and gender distribution of the sam- 
Table I Gender and racial distribution of the study sample

\begin{tabular}{|l|c|l|}
\hline Gender & 42 & \\
Female & 13 & $\mathrm{n}=55$ \\
Male & & \\
Previously classified as: & & \\
black & 24 & \\
white & 23 & \\
Asian & 6 & \\
Coloured & 2 & $\mathrm{n}=55$ \\
\hline
\end{tabular}

ple is shown in Table I and the ages of the subjects in Figure 1.

Although the sample was small, it reflected the classic gender distribution of three out of four cases with rheumatoid arthritis being female (Melvin 1989: 45). The ages ranged between 20 and 74 years, with an average age for the whole sample of 48.5 years. The average for the males as 44.5 years and the females 53.4 years.
Most male subjects had had the disease for less than six years, while most of the females fell in the 6-10 years duration category. Not one of the male subjects had had the disease longer than 21 years. The longest duration for females was 30 years. The duration of the disease for males and females is shown in Figure 2.

\section{Questionnaire administered to respondents}

The questionnaire recorded the following:

\section{a) Level of independence}

The researchers used a list of questions and the scoring method from the Stanford Health Assessment Questionnaire (SHAQ) to document patients' level of difficulty in ADL. The SHAQ is reported as a reliable and valid instrument for the rheumatoid arthritis population (Deighton, Surtees \&Walker 1992: 473; Ramey, Raynauld \& Fries 1992: 121 and Ward 1994: 24). It is a self-report instrument on which patients rate the degree of difficulty they experience in everyday tasks. The scoring is as follows: $1=$ no difficulty, $2=$ some difficulty, $3=$ much difficulty and $4=$ unable to do (Kirwan \& Reeback 1986:207).

The tasks listed in the SHAQ require unilateral and bilateral

\section{Figure 2 Duration of disease (yrs)}

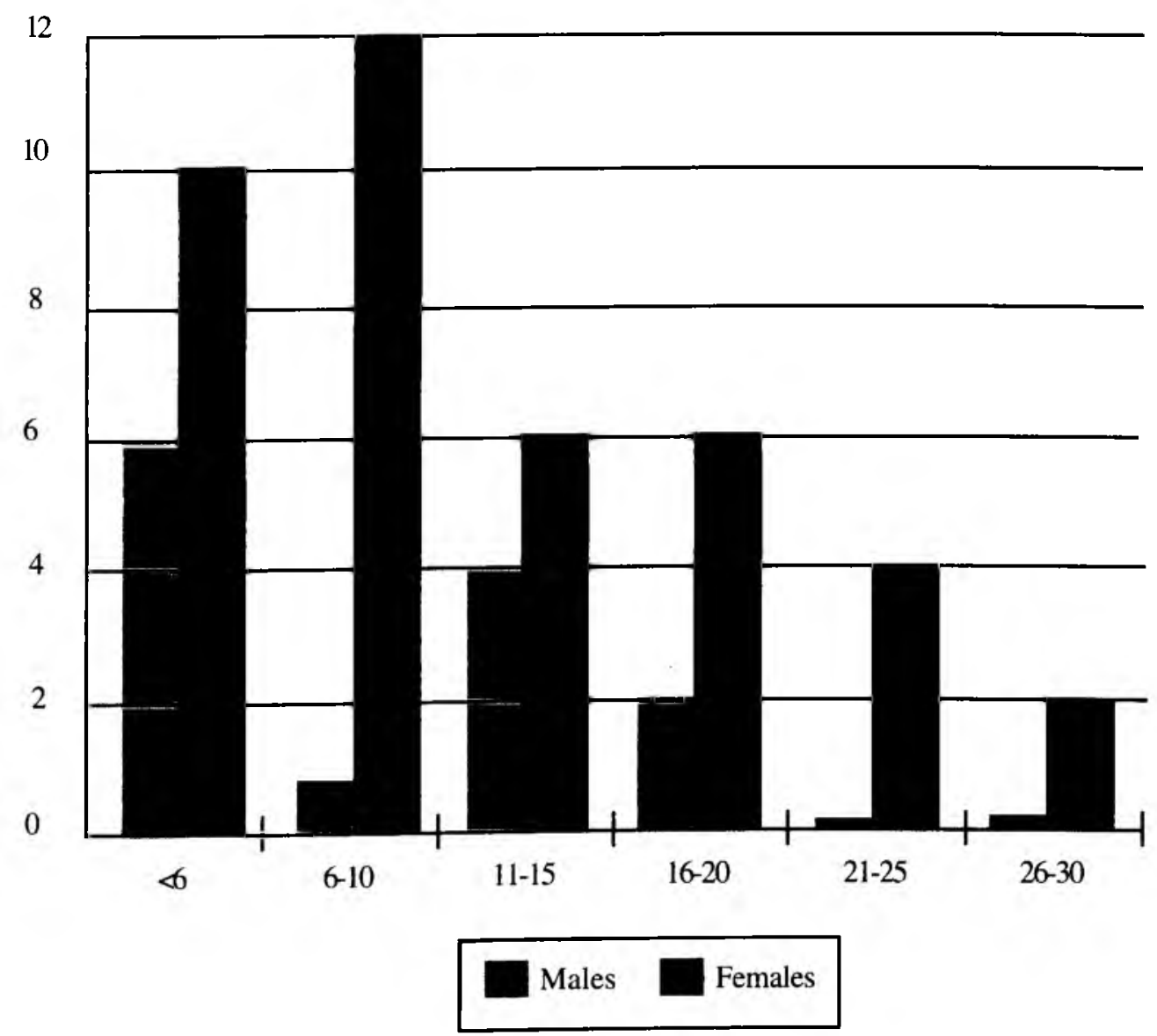


Table 2 List of tasks in the questionnaire

\begin{tabular}{|ll|}
\hline \multicolumn{2}{|l|}{ List of tasks } \\
\hline$\cdot$ & Cutting meat \\
\hline - & Opening a car door \\
\hline$\cdot$ & Unlocking a door \\
\hline$\cdot$ & Writing \\
\hline$\cdot$ & Opening/closing tap \\
\hline - & $\begin{array}{l}\text { Picking up money and extracting } \\
\text { from purse/wallet/pocket }\end{array}$ \\
\hline - & Doing and undoing buttons \\
\hline
\end{tabular}

hand use, as well as strength and dexterity. The list is shown in Table II.

\section{b) Assistive devices}

The second part of the questionnaire recorded details of assistive devices that had previously been issued to the patient and which assistive devices were still being used. It also provided for recording a request and need for an additional assistive device.

For the purpose of this study the researchers classified the assistive devices available according to whether they compensate for the loss of:

- $\quad$ strength
- dexterity

- $\quad$ both strength and dexterity

(See Table III)

\section{Instruments for measuring grip strength}

Various instruments are available to measure grip strength, with the Jamar dynamometer being reported as the most accurate and reliable (Lusardi, Bohannon $1991: 117$ \& Innes $1999: 134)$. It is, however, expensive, heavy and uncomfortable for people with weak and painful hands. The rigidity and shape of the instrument causes pain and inhibits the application of force.

An alternative to the dynamometer for patients with rheumatoid arthritis is the modified sphygmomanometer (Figure 3). A criticism of pneumatic instruments, such as a sphygmomanometer to measure grip strength, is that the pressure measurement is dependent on the surface area over which the force is applied. If the area is small, the force will register as a greater pressure, than if the same force is spread over a larger area. It is therefore important to ensure maximum contact between the hand and the cuff during measurement (Innes 1999: 121).

Giles (1984 : 36), in reviewing grip strength testing, concluded that the modified sphygmomanometer is an objective and easily applied measurement. It is inexpensive and does not have the drawbacks of the Jamar dynamometer. (Balogun,Akomolafe, Amusa 1990: 290; Melvin 1989: 354). A sphygmomanometer is readily available at Primary Health Care sites.

For reasons of comfort and pain avoidance it was decided

\section{Table III Classification of Assistive Devices Assistive devices used, requested and needed}

\begin{tabular}{|l|l|c|c|c|c|}
\hline $\begin{array}{c}\text { Compensate for } \\
\text { loss of: }\end{array}$ & $\begin{array}{c}\text { Assistive device } \\
\text { available at the clinic }\end{array}$ & In use & Requested & Still needed & "Total interest" \\
\hline Strength & Dagger knife with built- & 30 & 4 & 2 & 36 \\
& up handle & 18 & 8 & 2 & 28 \\
& Tap turner & 8 & 1 & 1 & 10 \\
& Dycem & 4 & 0 & 0 & 4 \\
& Tubing & 2 & 0 & 1 & 3 \\
& Kettel tipper & 2 & 0 & 0 & 2 \\
& Key holder & 9 & 2 & 2 & 13 \\
& Button hook & 1 & 0 & 0 & 1 \\
\hline Dexterity & Adapted scizzors & 3 & 2 & 1 & 6 \\
& Potato peeler & 0 & 3 & 2 & 5 \\
\hline \multirow{2}{*}{ Both strength } \\
and dexterity & Adapted nail clipper & 2 & 0 & 1 & 3 \\
& Pencil grip & & & & \\
\hline
\end{tabular}


Figure 3 Modified sphygmomanometer

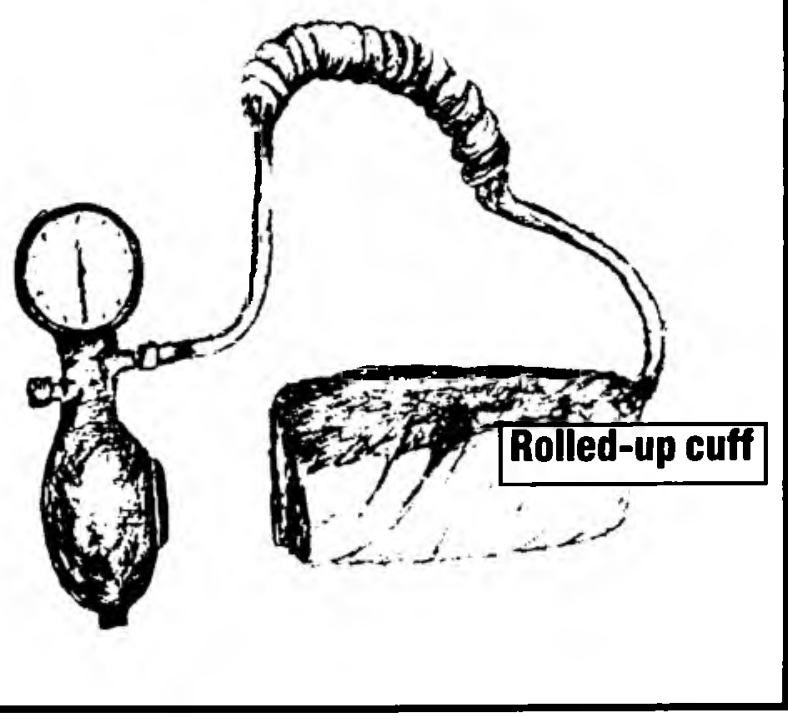

to use the modified aneroid sphygmomanometer with a nylon cuff for the research. A standard sphygmomanometer was modified by folding the cuff into three parts and inserting it into a cloth bag (See Figure 3).

The standard procedure described by Melvin (1989: 354) was used, with the sphygmomanometer pre-inflated to 30 $\mathrm{mmHg}$. Patients were encouraged to press the rolled-up cuff once as hard as they could. The American Society of Hand Therapists also emphasize the elbow flexion position, with the forearm midway between pro- and supination during testing and caution against supporting the elbow or forearm in any way (Lusardi and Bohannon 1991: 118 and Mathiowitz 1985: 695).

\section{Ethical considerations}

The research proposal was submitted to the University of Pretoria's Faculty of Health Sciences' Research Ethics Committee. Ethical clearance was granted for the study (clearance certificate number 152/2001).

The researchers obtained written, informed consent from participants. A data sheet was made available and the content explained to participants. They were advised that participation was voluntary and could withdraw from the study at any time.

\section{Data collection}

The researchers measured patients' grip strength. After this the following was recorded:

- Assistive devices in use.

- The assistive device requested by the patient. (This was then issued.)

- The need for another assistive device that would be issued at a subsequent visit to the clinic.

\section{Data analysis and results}

Descriptive statistics and correlations were used to analyse the data.

\section{Grip strength}

The mean grip strength of the dominant and nondominant hand in the males and females is shown in Figure 4.

The age and disease duration distribution in the two groups is not equal, and direct comparisons of strength between men and woman can therefore not be made.

\section{Difficulty in ADL}

See Figure 5 for difficulty in ADL experienced by the respondents.

\section{Figure 4 Grip strenght of male and female}

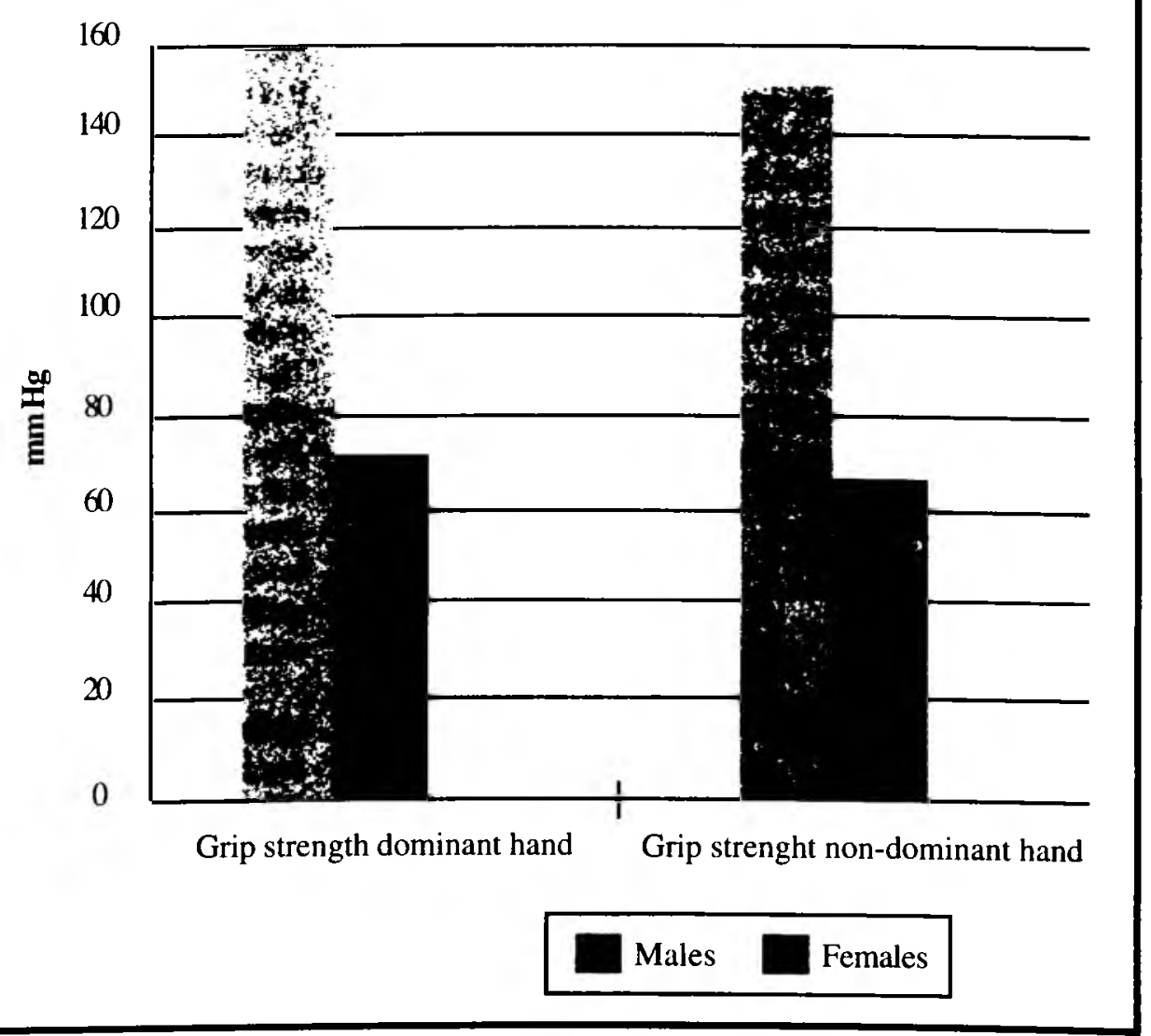




\begin{tabular}{|l|l|c|}
\hline \multicolumn{1}{|c|}{ Variable } & \multicolumn{1}{|c|}{ Variable } & Direction and extent of correlation \\
\hline Grip strength & Number of assistive devices & -0.3232 \\
\hline Grip strength & Difficulty in ADL & -0.5430 \\
Dominant hand \\
Non-dominant hand & & -0.4677 \\
\hline Difficulty in ADL & & 0.3467 \\
& Number of assistive devices & 0.048 \\
\hline Grip strength & Disease duration & \\
Dominant hand & Disease duration & -0.3 \\
Non-dominant hand & & -0.4 \\
\hline
\end{tabular}

Most difficulty was found with the activities that require strength, namely turning a tap, cutting, and opening and unlocking doors. Tasks that required dexterity, (writing, doing buttons and handling money) were generally not a problem. For instance, handling money was the activity for which nobody scored an "unable to do". One patient was illiterate and could not comment on difficulty with writing. Two patients reported that unlocking a door was not applicable to them.

\section{Assistive devices in use, requested and still needed}

Table III shows which assistive devices were in use, requested and needed.

The men in the study hardly used or requested assistive devices. A total of ninety assistive devices were in use, of which only four were used by males. Twenty three devices were requested, of which only two by males. Male patients made no request for more devices. This confirms findings from Dellhag and Bjelle $(1999: 36)$ who found that women had on average three times as many devices available than men. In their study women also used more of the devices available than men.

Eighty three percent (83\%) of all assistive devices in use are designed to compensate for loss of strength. Of this group of assistive devices, dagger knives with built-up handles and tap turners were most in use, and also most often requested.

Eleven percent (11\%) of assistive devices that were in use and requested were to compensate for loss of dexterity.

The remaining devices, (5.8\% of the total), combined features to compensate for loss of both dexterity and strength.

\section{Correlations}

Because of the ordinal nature of the data, non-parametric statistics (Spearman Rank Correlations) were done (Payton
1994: 63) to test for correlations between

- $\quad$ grip strength and the

o number of assistive devices,

o duration of disease,

o degree of difficulty in performing ADL and

- investigate whether there was a correlation between difficulty in ADL and

o the number of assistive devices,

o duration of disease

Results are summarized in Table IV.

The strongest correlations were between grip strength and difficulty in ADL ( 0.47 and 0.54 for the two hands), and between difficulty in ADL and the number of assistive devices $(0.34)$.

\section{Discussion}

It is to be expected that the weaker the grip, the more difficult ADL would be, and that more assistive devices would be used. The moderate correlation between duration of disease and grip strength is also not unexpected. The lack of correlation between the duration of disease and difficulty in ADL may be an indication of people's ability to adapt to their impaired hand function in spite of loss of grip strength. The loss of strength may also, at least partially, be due to normal loss of strength with ageing.

The greater use by female subjects of assistive devices in the study supports work by Dellhag \& Bjelle (1999:36). They explain this greater use by the fact that women in the study were more severely affected than men. Another explanation they offer is that many of the devices handed out were intended for household use.

It must also be borne in mind that life style, socio economic conditions and attitude towards disease and disability could also influence the need for and the use of assistive devices.

\section{Limitations of the study}

Patients were not asked to indicate why they used, or did 


\section{Figure 5 Difficulty with ADL}

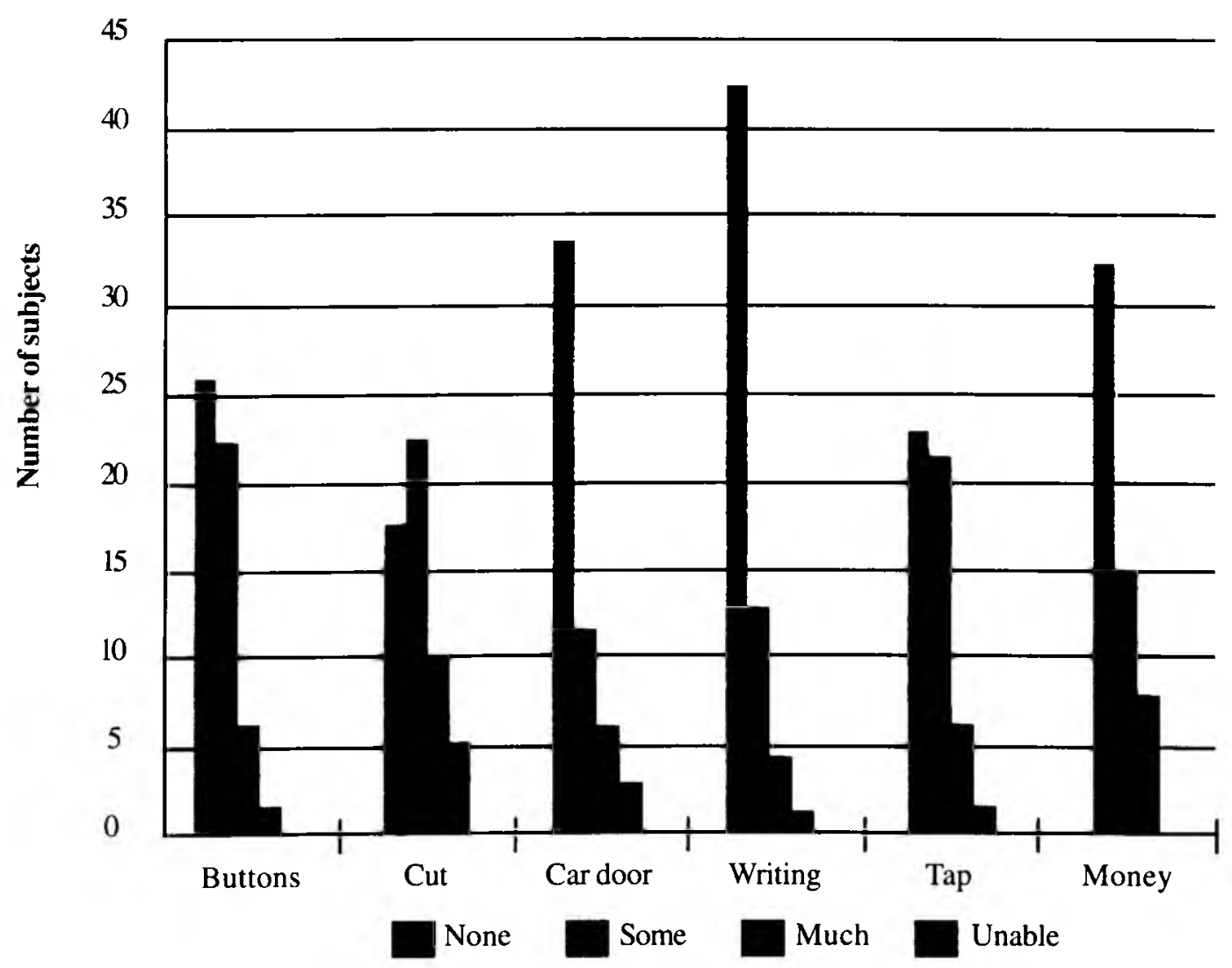

not use the assistive devices that had been issued to them, nor were they asked whether they used them continuously or intermittently. It is therefore not possible to get the "big picture" of the use of assistive devices in the reported patient group. The relatively small sample size also makes it difficult to extrapolate the results to the patient population.

\section{Conclusion}

From the survey it is clear that the category of assistive devices that compensate for loss of grip strength have priority for the Essential Assistive Devices List at Primary Health Care facilities, with tap turners and dagger knives with built-up handles the items most needed. This is supported by the moderate to strong negative correlation between the grip strength and difficulty in ADL.

It is therefore justified both from an empirical and theoretical perspective, to start the Essential Assistive Devices List with tap turners and dagger knives with built-up handles.

A number of issues still need to be researched around the assistive devices issued at the arthritis clinic, like recording the effect of using assistive devices on pain and discomfort during ADL; investigating positive and negative experiences of using assistive devices; difference in need for of assistive devices for patients with predominantly wrist involvement and those with predominantly metacarpal phalangeal joint involvement.

\section{References}

BALOGUN,JA, AKOMOLAFE, CT \& AMUSA, LO 1990: Reproducibility and criterion-related validity of the modified sphygmomanometer for isometric testing of grip strength. Physiotherapv Canada. 42: 6290 - 295.

DEIGHTON, C, SURTEES, D \& WALKER DJ 1992: Influence of the severity of rheumatoid arthritis on sex difference in Health Assessment Questionnaire Score. Annals of Rheumatic Disease. 51: 473 - 475.

DELLHAG, B \& BJELLE, A 1999: A five-year follow-up of hand function and ADL in rheumatoid arthritis patients. Arthritis Care and Research. 12(1): 33 - 41.

DELLHAG, B \& BURCKHARDT, CS 1995: Predictors of hand function in patients with rheumatoid arthritis. Arthritis Care and Research. 8(1): 16-20.

FELSON, DT; ANDERSON, JJ; BOERS, M; BOMBARDIE, C; CHERNOFF, M; FRIED, B FURST, D; GOLDSMITH,C KIESZAK,S:LIGHTFOOT,R; PAULUS, H; TUGWELL, P; WEINBLATT, M; WIDMARK, R; WLLIAMS, HJ; WOLFE, F 1993: The American College of Rheumatology preliminary core set of disease activity measures for rheumatoid arthritis clinical trials. Arthritis and Rheumatism. 36(6): 729 - 740.

GILES, C 1984. The modified sphygmomanometer: An 
instrument to objectively assess muscle strength. Phvsiotherapy Canada. Jan/Feb 36(1): 36 - 38.

HOPKINS, HL AND SMITH HD 1993: Willard and Spackman's Occupational Therapy. $8^{\text {th }}$ edition: (326). Philadelphia: JB Lippincott.

INNES, E 1999: Handgrip strength testing. A review of the literature. Australian Occupational Therapy Journal. 46: $120-140$.

KIRWAN, JR \& REEBACK, JS 1986: SHAQ modified to assess disability in British patients with Rheumatoid Arthritis. British Journal of Rheumatology. 25: 206 - 209.

LUSARDI, MM \& BOHANNON, RW 1991: Hand grip strength: Comparability of measurement obtained with a Jamar Dynamometer and a Modified Sphygmomanometer. Journal of Hand Therapy. July - September: 117 - 122.

MATHIOWETZ, V, RENNELS,C \& DONAHOE.L 1985: Effect of elbow position on grip and key pinch strength. Journal of Hand Surgery, 10A (5): 694 - 696.

MELVIN, JL 1989: Rheumatoid disease in the adult and child. Occupational Therapy and Rehabilitation. $3^{\text {rd }}$ edition (45), (439-454). Philadelphia: FA Davis.

MYERS, DB, GRENNAN,DM\& PALMER,DG 1980: Hand grip function in patients with Rheumatoid Arthritis. Archives of Physical Medicine and Rehabilitation. 61: 369 . 373.

National Rehabilitation Policy Nov 2000: Rehabilitation for all. Pretoria: Department of Health, p18.

PALMER, P \& SIMONS, J 1991: Joint protection: A critical review. British Joumal of Occupational Therapy. 54 (12): 452-458.

PAYTON, OD 1994: Research: Validation of Clinical Practice. $3^{\text {rd }}$ edition (63). Philadelphia: FA Davis.

RAMEY, DR, RAYNAULD, JP \& FRIES JF 1992: The Health Assessment Questionnaire. Arthritis Care and Research, 5(3): 119 - 129.

REED, $K$ \& SANDERSON, SR 1980: Concepts of occupational therapy. (227). Baltimore: Williams \& Wilkins.

SHIPHAM I 1996: Ulnar drift of the fingers - biomechanics and measurement of increase during resisted pinch. SA Journal of Occupational Therapy, 26(1) 32-36.

WARD, MM 1994: Clinical measures in Rheumatoid Arthritis: Which are most useful in assessing patients? Journal of Rheumatology, 21(1): 17-27. 